\title{
Two Forms of Astrocyte Calcium Excitability Have Distinct Effects on NMDA Receptor-Mediated Slow Inward Currents in Pyramidal Neurons
}

\author{
Eiji Shigetomi, ${ }^{1,2}$ David N. Bowser, ${ }^{3}$ Michael V. Sofroniew, ${ }^{2}$ and Baljit S. Khakh ${ }^{1,2,3}$ \\ Departments of ${ }^{1}$ Physiology and ${ }^{2}$ Neurobiology, David Geffen School of Medicine, University of California, Los Angeles, California 90095-1751, and \\ ${ }^{3}$ Medical Research Council Laboratory of Molecular Biology, Cambridge CB2 0QH, United Kingdom
}

\begin{abstract}
Astrocytes display excitability in the form of intracellular calcium concentration $\left(\left[\mathrm{Ca}^{2+}\right]_{\mathrm{i}}\right)$ increases, but the signaling impact of these for neurons remains debated and controversial. A key unresolved issue is whether astrocyte $\left[\mathrm{Ca}^{2+}\right]_{\mathrm{i}}$ elevations impact neurons or not. Here we report that in the CA1 region of the hippocampus, agonists of native $\mathrm{P}_{2} \mathrm{Y}_{1}$ and PAR-1 receptors, which are preferentially expressed in astrocytes, equally elevated $\left[\mathrm{Ca}^{2+}\right]_{\mathrm{i}}$ levels without affecting the passive membrane properties of pyramidal neurons. However, under conditions chosen to isolate NMDA receptor responses, we found that activation of PAR-1 receptors led to the appearance of NMDA receptor-mediated slow inward currents (SICs) in pyramidal neurons. In stark contrast, activation of P2Y ${ }_{1}$ receptors was ineffective in this regard. The PAR-1 receptor-mediated increased SICs were abolished by several strategies that selectively impaired astrocyte $\left[\mathrm{Ca}^{2+}\right]_{\mathrm{i}}$ excitability and function. Our studies therefore indicate that evoked astrocyte $\left[\mathrm{Ca}^{2+}\right]_{\mathrm{i}}$ transients are not a binary signal for interactions with neurons, and that astrocytes result in neuronal NMDA receptor-mediated SICs only when appropriately excited. The data thus provide a basis to rationalize recent contradictory data on astrocyte-neuron interactions.
\end{abstract}

Key words: astrocyte; calcium; SIC; gliotransmitter; astrocytic glutamate release; glia

\section{Introduction}

Astrocytes, a type of glial cell, are found in the brain, and their close spatial relationship to neurons is well documented (Araque et al., 2001; Haydon, 2001). In addition to their important housekeeping roles (Kofuji and Newman, 2004), increasing evidence now suggests that astrocytes also actively participate in neuronal function (Haydon, 2001; Newman, 2003b; Fields, 2004; Fields and Burnstock, 2006).

Astrocytes do not fire action potentials. However, they display spontaneous and pharmacologically evoked intracellular $\mathrm{Ca}^{2+}$ concentration $\left(\left[\mathrm{Ca}^{2+}\right]_{\mathrm{i}}\right)$ increases, which represent a form of astrocyte excitability. Since their initial discovery (Cornell-Bell et al., 1990) in astrocyte cultures, $\left[\mathrm{Ca}^{2+}\right]_{\mathrm{i}}$ increases have been extensively studied for in vitro preparations of brain slices (Haydon, 2001; Parri et al., 2001; Newman, 2003b; Fields, 2004), and have also been recorded from astrocytes in vivo with two-photon calcium imaging from the cortex (Hirase et al., 2004). Thus $\left[\mathrm{Ca}^{2+}\right]_{\mathrm{i}}$ elevations appear to be a widespread and prevalent feature of astrocytes, can be triggered by neuronal activity, and are known to occur independently of neuronal activity resulting from intra-

Received April 20, 2008; revised May 15, 2008; accepted May 16, 2008.

This work was supported partly by the Medical Research Council, the Whitehall Foundation, and the Stein/ Oppenheimer Endowment Award (B.S.K.) and an Uehara Memorial Foundation Fellowship (Japan) (E.S.).

Correspondence should be addressed to Baljit $S$. Khakh, Department of Physiology, University of California, Los Angeles, 10833 LeConte Avenue, 53-263 CHS, Los Angeles, CA 90095-1751. E-mail: bkhakh@mednet.ucla.edu.

D. N. Bowser's present address: Howard Florey Institute, University of Melbourne, Parkville, Victoria 3010, Australia.

DOI:10.1523/JNEUROSCI.1717-08.2008

Copyright $\odot 2008$ Society for Neuroscience $\quad$ 0270-6474/08/286659-05\$15.00/0 cellular $\mathrm{Ca}^{2+}$ release (Newman, 2003a; Parri and Crunelli, 2003). Moreover, it is now well established that astrocyte $\left[\mathrm{Ca}^{2+}\right]_{\mathrm{i}}$ increases trigger release of transmitters into the extracellular space. The evidence in favor of this is derived from a variety of approaches, including biochemical, amperometric, and capacitance methods, as well as single-vesicle imaging (Araque et al., 2000; Krzan et al., 2003; Bezzi et al., 2004; Evanko et al., 2004; Kreft et al., 2004; Zhang et al., 2004a,b; Bowser and Khakh, 2007a; Jaiswal et al., 2007). One of the transmitters known to be released from astrocytes is glutamate.

The realization that astrocytes display $\left[\mathrm{Ca}^{2+}\right]_{\mathrm{i}}$ elevations and that they display calcium-triggered glutamate release raises the possibility that astrocytic glutamate could affect neurons. This issue has been addressed in the past, and we restrict ourselves here to the most pertinent experiments for the CA1 region of the hippocampus. In one study, NMDA receptor-mediated slow inward currents (SICs) were recorded from CA1 pyramidal neurons when (S)-3,5-dihydroxyphenylglycine (DHPG) was used to activate metabotropic glutamate receptors on astrocytes and thus trigger $\left[\mathrm{Ca}^{2+}\right]_{\mathrm{i}}$ elevations (Fellin et al., 2004). However, a recent study has questioned the use of DHPG because of its attendant actions on neurons (Fiacco et al., 2007). Instead these authors used the creative approach of using an exogenous MrgA1 receptor selectively expressed in astrocytes to elevate $\left[\mathrm{Ca}^{2+}\right]_{\mathrm{i}}$ within them. They found that when astrocyte $\left[\mathrm{Ca}^{2+}\right]_{i}$ levels were elevated by activating $\mathrm{MrgA} 1$ receptors, this did not result in the appearance of SICs in pyramidal neurons (Fiacco et al., 2007). Thus, the starkly contrasting conclusions between groups (Fellin 
et al., 2004; Fiacco et al., 2007) leaves open the question of whether astrocyte $\left[\mathrm{Ca}^{2+}\right]_{\mathrm{i}}$ elevations impact neurons or not (Tritsch and Bergles, 2007). In the present study, we returned to the issue of whether astrocyte $\left[\mathrm{Ca}^{2+}\right]_{\mathrm{i}}$ elevations can cause the appearance of SICs on pyramidal neurons.

\section{Materials and Methods}

Preparation of brain slices and electrophysiological recording. The methods used have been described previously (Khakh et al., 2003; Bowser and Khakh, 2004). Briefly, young [postnatal day 11 (P11)-P19] C57 mice were killed in accordance with institutional procedures. In some cases, GFAP-green fluorescent protein (GFP) mice were used, and these were available from previous work (Garcia et al., 2004). Coronal slices of hippocampus $(200$ or $300 \mu \mathrm{m})$ were cut (model 1000 or 3000 Plus Vibratome) and submerged at room temperature in artificial CSF (aCSF) comprising the following (in $\mathrm{mM}$ ): $126 \mathrm{NaCl}, 2.5 \mathrm{KCl}, 1.3 \mathrm{MgCl}_{2}, 10$ D-glucose, $2.4 \mathrm{CaCl}_{2}, 1.24 \mathrm{NaH}_{2} \mathrm{PO}_{4}$, and $26 \mathrm{NaHCO}_{3}$ saturated with $95 \% \mathrm{O}_{2}$ and $5 \% \mathrm{CO}_{2}$. Experiments were performed with potassium gluconate or chloride-based internal solution, comprising the following (in $\mathrm{mM}$ ): $120 \mathrm{~K}$ gluconate $\left(\right.$ or $\mathrm{Cl}^{-}$), $10 \mathrm{KCl}, 1 \mathrm{MgCl}_{2}, 0.03 \mathrm{CaCl}_{2}, 0.1 \mathrm{EGTA}$, 1 ATP, 0.2 GTP, 10 HEPES, and 4 glucose, $\mathrm{pH} 7.25$. The resistance of the pipettes was $\sim 4-9 \mathrm{M} \Omega$. Cells were visualized with infrared optics (Luigs and Neumann) on an upright microscope (Olympus BX50). We used bath application of agonists. Inward currents were recorded at $-60 \mathrm{mV}$ using pCLAMP 9 software, Multiclamp 900A amplifier, and Digidata 1322A (Molecular Devices). Spontaneous EPSCs were recorded in the presence of bicuculline $(10 \mu \mathrm{M})$ and D-(-)-2-amino-5-phosphonopentanoic acid (D-AP5; $10 \mu \mathrm{M}$ ). Slow inward currents (Fellin et al., 2004) mediated by extrasynaptic NMDA receptors were recorded in low- $\mathrm{Mg}^{2+}$ buffers $(0.13 \mathrm{mM})$ in the presence of bicuculline $(10 \mu \mathrm{M})$, TTX $(1 \mu \mathrm{M})$, and 6-cyano-2,3-dihydroxy-7-nitroquinoxaline (CNQX; $10 \mu \mathrm{M}$ ). Astrocytes were patched with 4-9 M $\Omega$ electrodes filled with an intracellular solution comprising $123 \mathrm{CsCl}, 1 \mathrm{MgSO}_{4}, 10 \mathrm{HEPES}, 1 \mathrm{ATP}, 0.2 \mathrm{GTP}, \mathrm{pH}$ 7.35 , and $100 \mu \mathrm{M}$ Alexa Fluor 488 (referred to as Alexa 488 in the text), and BAPTA (10 mM) as indicated in the text (Jourdain et al., 2007).

Confocal imaging of astrocyte $\mathrm{Ca}^{2+}$ activity and dialysis. Brain slices were loaded at room temperature in the dark with $5 \mu \mathrm{M}$ Fluo-4 AM (Invitrogen) in aCSF for $60 \mathrm{~min}$, then transferred to dye-free aCSF for at least 30 min before experimentation to allow for cleavage of the AM ester group (Porter and McCarthy, 1996). Live astrocytes were predominantly loaded with the fluorescent dye with these conditions. This was confirmed by simultaneous acquisition of infrared-differential interference contrast (IR-DIC) images of astrocytes in the same area. Cells and slices were imaged using an Olympus Fluoview 300 laser-scanning confocal microscope with a $300 \mathrm{~mW}$ argon laser, at $<10 \%$ power. Emitted green fluorescence was collected through a 515 long-pass filter. Fluoview software was used for image acquisition. For BAPTA and Alexa 488 dialysis, the astrocytes were held at $-80 \mathrm{mV}$, and depolarized to $0 \mathrm{mV}$ for $100 \mathrm{~ms}$ every $30 \mathrm{~s}$ to monitor access resistance. The optimal dialysis time was empirically determined to be $15 \mathrm{~min}$ after patching. Astrocyte dialysis with Alexa 488 was measured from confocal stacks for $90 \mu \mathrm{m}$ depth from the surface of the brain slices for the stratum radiatum region within $150-200 \mu \mathrm{m}$ of the CA1 pyramidal cell layer. We counted all astrocytes in this layer that were visibly fluorescent (see Results).

Chemicals. All chemicals used were from Tocris Bioscience, Sigma, or Invitrogen. The chemicals used were CNQX, D-AP5, and adenosine $5^{\prime}$ $\beta$-thio diphosphate (ADP $\beta S$ ).

Analysis. Synaptic currents were analyzed using MiniAnalysis program 5.6.22 (Synaptosoft), Strathclyde Electrophysiology Software (John Dempster, University of Strathclyde, Glasgow, UK), pCLAMP9 (Molecular Devices), Origin 6.1 (OriginLab), and GraphPad Instat 3.06 for Windows. Confocal and epifluorescence imaging data were analyzed using ImageJ and CorelDraw 12. Data in the text and graphs are shown as mean \pm SEM from $n$ determinations as indicated.

\section{Results}

$\mathrm{P}_{2} \mathrm{Y}_{1}$ and PAR-1 receptor agonists excite astrocytes

We recently demonstrated that agonists of $\mathrm{P}_{2} \mathrm{Y}_{1}$ and PAR-1 receptors both elevate astrocyte $\left[\mathrm{Ca}^{2+}\right]_{\mathrm{i}}$ levels and triggered single-

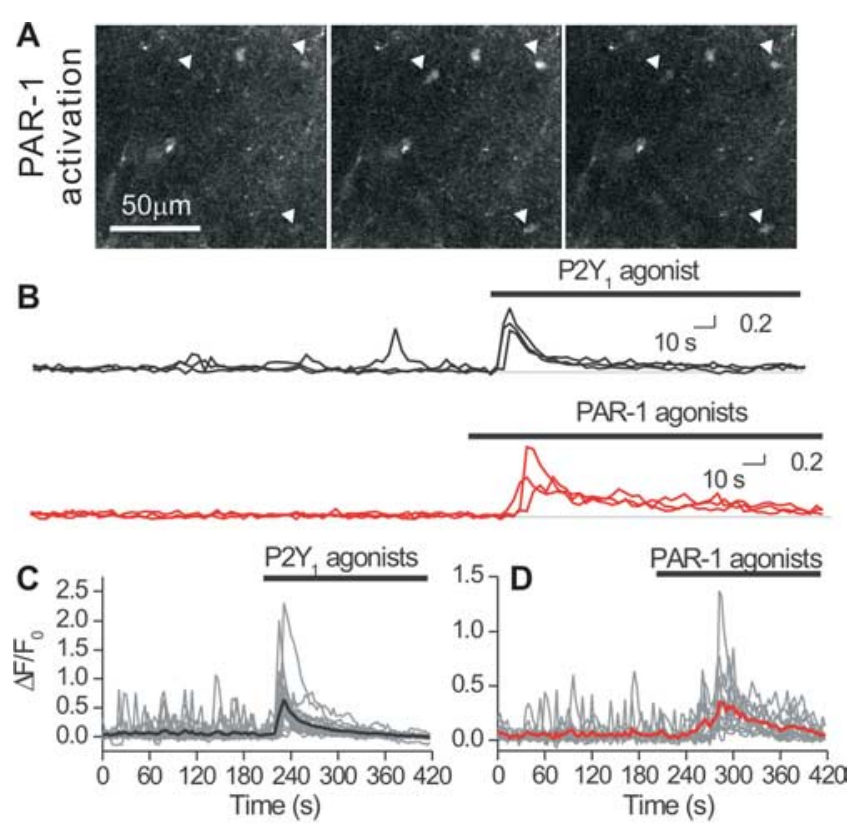

E

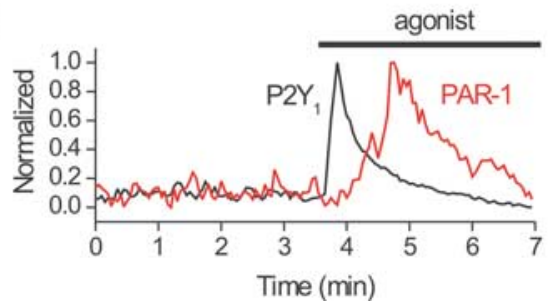

Figure 1. Astrocyte $\left[\mathrm{Ca}^{2+}\right]_{\mathrm{i}}$ transients evoked by activation of $\mathrm{P} 2 \mathrm{Y}_{1}$ and PAR-1 receptors. $\boldsymbol{A}$, Representative images of the stratum radiatum region of the hippocampus with astrocytes showing increases in $\left[\mathrm{Ca}^{2+}\right]_{\mathrm{i}}$ during activation of PAR-1 receptors with TFLLR peptide (30 $\left.\mu \mathrm{m}\right)$. Arrowheads point to astrocytes showing intracellular calcium transients. $\boldsymbol{B}$, Exemplar traces PAR-1- and P2Y $\mathrm{Y}_{1}$-evoked $\left[\mathrm{Ca}^{2+}\right]_{\mathrm{i}}$ transients. $\boldsymbol{C}, \boldsymbol{D}$, Pooled data for experiments such as those in $\boldsymbol{A}$. The gray lines are individual cells, and the solid lines are the averages from all cells. Activation of both $P 2 Y_{1}$ and PAR- 1 receptors evoked increases in astrocyte $\left[\mathrm{Ca}^{2+}\right]_{i}$ levels. $\boldsymbol{E}$, The average normalized traces for $\left[\mathrm{Ca}^{2+}\right]_{i}$ transients evoked by $\mathrm{P} 2 \mathrm{Y}_{1}$ and PAR-1 receptor activation; note that there was a latency for the PAR-1-mediated responses in relation to those mediated by $\mathrm{P}_{2} \mathrm{Y}_{1}$ receptors, and their duration was longer.

vesicle exocytosis in culture (Bowser and Khakh, 2007a). PAR-1 receptors are known to be preferentially expressed within astrocytes of the hippocampus (Weinstein et al., 1995; Junge et al., 2004; Lee et al., 2007). Thus, $\mathrm{P}_{2} \mathrm{Y}_{1}$ and PAR-1 receptors are useful targets to increase astrocyte $\left[\mathrm{Ca}^{2+}\right]_{\mathrm{i}}$ levels, and determine whether this affects neurons in brain slices. To this end, we started by loading astrocytes in hippocampal slices with Fluo-4 $\mathrm{AM}$ and focused on the stratum radiatum region. We found that the $\mathrm{P}_{2} \mathrm{Y}_{1}$ receptor agonist $\mathrm{ADP} \beta \mathrm{S}(30$ or $100 \mu \mathrm{M})$, and PAR-1 receptor agonists thrombin $(10 \mathrm{U} / \mathrm{ml})$ and TFLLR-NH $\mathrm{N}_{2}(30 \mu \mathrm{M})$ elevated $\left[\mathrm{Ca}^{2+}\right]_{\mathrm{i}}$ in astrocytes within the stratum radiatum region. This is readily seen in the representative images and traces in Figure 1, $A$ and $B$, and Figure $1, C$ and $D$, shows 23 and 14 superimposed sweeps with the average data emphasized in thick lines. Interestingly, the PAR-1 agonist-evoked $\left[\mathrm{Ca}^{2+}\right]_{\mathrm{i}}$ transients were slower to develop compared with the $\mathrm{P}_{2} \mathrm{Y}_{1}$ receptor agonist ones (Fig. $1 E$ ), and although the evoked transients displayed equal peaks $\left(\Delta F / F\right.$ of $0.8 \pm 0.1$ and $0.6 \pm 0.1$ for $\mathrm{P}_{2} \mathrm{Y}_{1}$ and PAR- 1 receptors; $n=23$ and 14), the PAR-1-mediated events lasted significantly longer (the widths of the events at $25 \%$ of the peak height were $36 \pm 4$ and $77 \pm 9$ s, respectively, for $\mathrm{P}_{2} \mathrm{Y}_{1}$ and PAR-1 transients; $n=23$ and 14). We next used fura-2 AM-based imag- 
A
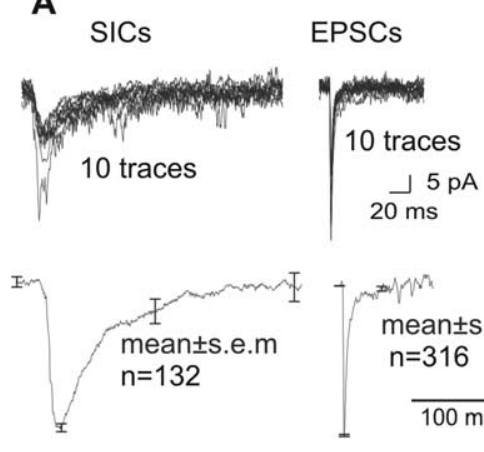

B

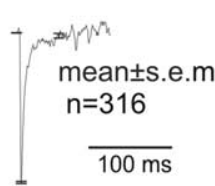

C

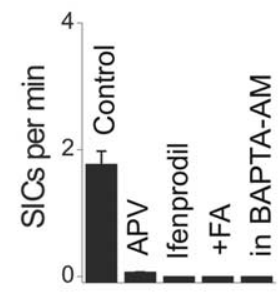

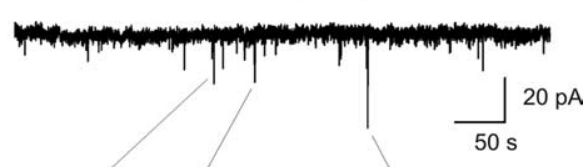

D

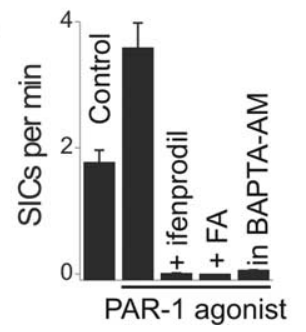

Figure 2. Effect of astrocyte $\left[\mathrm{Ca}^{2+}\right]_{\mathrm{i}}$ excitation on glutamatergic SICs onto pyramidal neurons. $\boldsymbol{A}$, Representative (top) and average (bottom) traces for SICs and EPSCs recorded from a pyramidal neuron (average data are presented in the text). $\boldsymbol{B}$, Activation of PAR-1 receptors led to the appearance of SICS. C, The spontaneous SICs were reduced or abolished with APV and ifenprodil, and in slices pretreated with FA and BAPTA-AM. D, PAR-1 agonist-evoked SICs were abolished in the presence of ifenprodil or in slices pretreated with FA or BAPTA-AM.

ing to estimate the change in astrocyte $\left[\mathrm{Ca}^{2+}\right]_{\mathrm{i}}$. We estimate that activation of $\mathrm{P}_{2} \mathrm{Y}_{1}$ and $\mathrm{PAR}-1$ receptors elevated astrocyte $\left[\mathrm{Ca}^{2+}\right]_{\mathrm{i}}$ levels to $\sim 0.5 \mu \mathrm{M}$ from a resting level of $\sim 50 \mathrm{nM}$ (for a specific set of experiments, the peaks were $407 \pm 69 \mathrm{nM}$ for $\mathrm{P} 2 \mathrm{Y}_{1}$ activation, $305 \pm 56 \mathrm{nM}$ for PAR-1 activation). Thus, within the stratum radiatum region of the hippocampus, agonists of $\mathrm{P} 2 \mathrm{Y}_{1}$ and PAR-1 receptors increase astrocyte $\left[\mathrm{Ca}^{2+}\right]_{\mathrm{i}}$ levels to the range expected to trigger glutamate release (Parpura and Haydon, 2000; Kreft et al., 2004). In contrast to their robust effect on astrocyte $\left[\mathrm{Ca}^{2+}\right]_{\mathrm{i}}$ levels (Fig. 1), in supplemental Figure 1 (available at www.jneurosci.org as supplemental material) we present several controls indicating that $\mathrm{P} 2 \mathrm{Y}_{1}$ and $\mathrm{PAR}-1$ receptor agonists do not alter pyramidal neuron excitability.

\section{Effects of astrocyte excitation on astrocyte-pyramidal neuron interactions}

We exploited the finding that $\mathrm{P} 2 \mathrm{Y}_{1}$ and $\mathrm{PAR}-1$ receptor activation evoked significant astrocyte $\left[\mathrm{Ca}^{2+}\right]_{\mathrm{i}}$ transients in slices (Fig. 1), as well as exocytosis (Bowser and Khakh, 2007a) to determine whether these affect CA1 pyramidal neurons. Electron microscopy has shown that astrocytes are intimately associated with neurons in the CA1 region (Bushong et al., 2002). We monitored slow inward currents (Fellin et al., 2004; Perea and Araque, 2005) mediated by extrasynaptic NMDA receptors (Fig. 2), which are distinct from EPSCs. The SICs were recorded at a holding potential of $-60 \mathrm{mV}$ in the presence of TTX, bicuculline, and CNQX $(1,10$, and $10 \mu \mathrm{M}$, respectively) in extracellular buffers with 10 fold-reduced $\mathrm{Mg}^{2+}(0.13 \mathrm{~mm})$. Based on previous work (Fellin et al., 2004), we identified the SICs because of their slow rise times $(10-90 \%$ rise time $=46 \pm 18 \mathrm{~ms})$, slow decay times $(\tau=196 \pm$ $92 \mathrm{~ms})$, and low frequency $(0.03 \pm 0.005 \mathrm{~Hz}$; the amplitude was $-29 \pm 1 \mathrm{pA} ; n=132)$. In contrast to SICs, synaptic EPSCs were faster $(10-90 \%$ rise time $=1.2 \pm 0.06 \mathrm{~ms}$; decay $\tau=6.6 \pm 1.4$ $\mathrm{ms})$ and more frequent $(0.66 \pm 0.09 \mathrm{~Hz}$; the amplitude was

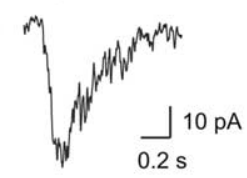

$-43 \pm 1 \mathrm{pA} ; n=316)$. Both the SICs and EPSCs reported here for 200 - to $300-\mu$ m-thick mouse coronal hippocampal slices were approximately twice as fast (rise and decay) as those reported previously from 300- to 400$\mu \mathrm{m}$-thick rat transverse hippocampal slices (Fellin et al., 2004), but nonetheless readily distinguishable from each other (Fig. 2A). To test whether SICs were indeed caused by astrocyte release of glutamate acting on extrasynaptic NMDA receptors, we tested the actions of the NR2B antagonist ifenprodil (10 $\mu \mathrm{M} ; n=8)$, which selectively blocks SICs mediated by astrocytes (Fellin et al., 2004). The presence of ifenprodil, or APV, reduced or abolished spontaneous SICs $(n=8)$ (Fig. $2 C)$, suggesting that SICs were mediated by extrasynaptic NMDA receptors (Fellin et al., 2004).

The $\mathrm{P}_{2} \mathrm{Y}_{1}$ agonist ADP $\beta$ S produced no effect on the holding current of pyramidal neurons ( $\sim 1$ pA change; $n=19)$ and no effect on SICs $(1.8 \pm 0.3 \mathrm{SICs} / \mathrm{min}$ before ADP $\beta S$ and $1.5 \pm 0.3 \mathrm{SICs} / \mathrm{min}$ during $\mathrm{ADP} \beta S ; n=8)$. Thus, the effect of $\mathrm{P} 2 \mathrm{Y}_{1}$ receptor activation was minimal, suggesting that elevation of astrocyte $\left[\mathrm{Ca}^{2+}\right]_{\mathrm{i}}$ levels has little postsynaptic consequences for CA1 pyramidal neurons. Thrombin and TFLLR-NH $\mathrm{N}_{2}(10 \mathrm{U} / \mathrm{ml}$ and $30 \mu \mathrm{M})$, which activate PAR-1 receptors and elevate astrocyte $\left[\mathrm{Ca}^{2+}\right]_{\mathrm{i}}$ levels, produced no effect on the holding current of pyramidal neurons $(\sim 1 \mathrm{pA}$ change; $p>0.05$; $n=25)$. However, PAR-1 receptor activation increased the frequency of SICs mediated by extrasynaptic NMDA receptors (Fig. 2) (12/12 cells). To further explore the hypothesis that the PAR-1 receptorevoked SICs are of astrocyte origin, we used fluoroacetate (FA; slices were pretreated with $10 \mu \mathrm{M}$ FA for $2 \mathrm{~h}$ ) to selectively impair astrocyte function in brain slices (Fonnum et al., 1997; Gordon et al., 2005) and BAPTA-AM (Liu et al., 2004) to chelate astrocyte intracellular calcium (200 $\mu \mathrm{M}$ BAPTA-AM for $1.5 \mathrm{~h}$ followed by $30 \mathrm{~min}$ at room temperature). We loaded Fluo-4 AM together with BAPTA-AM, as well as into slices treated with FA, to verify that the $\left[\mathrm{Ca}^{2+}\right]_{\mathrm{i}}$ transients were abolished in astrocytes. They were: we did not observe any spontaneous $\mathrm{P}_{2} \mathrm{Y}_{1}$ - or PAR-1evoked $\left[\mathrm{Ca}^{2+}\right]_{\mathrm{i}}$ transients in slices treated with FA or BAPTAAM. Additionally, in slices treated with FA or BAPTA-AM, we observed no SICs (Fig. 2C) ( $n=5$ and 5) and no PAR-1 receptorevoked SICs (Fig. 2D) $(n=5$ and 5) in pyramidal neurons. Overall, these findings suggest that $\left[\mathrm{Ca}^{2+}\right]_{\mathrm{i}}$ transients in astrocytes evoked with $\mathrm{P}_{2} \mathrm{Y}_{1}$ agonist (Fig. 1) result in minor postsynaptic effects on pyramidal neurons. In contrast, $\left[\mathrm{Ca}^{2+}\right]_{\mathrm{i}}$ transients evoked with PAR-1 receptor agonists (Fig. 1) result in postsynaptic extrasynaptic NMDA responses (Fellin et al., 2004; Perea and Araque, 2005) in pyramidal neurons (Fig. 2). We performed controls, which together show that BAPTA-AM and FA did not adversely affect synaptic currents or the passive and active membrane properties of pyramidal neurons (supplemental Fig. 1, available at www.jneurosci.org as supplemental material).

\section{Astrocyte dialysis with BAPTA impairs PAR-1 receptor-evoked SICs}

We next sought to dialyze astrocytes in brain slices with BAPTA through the patch pipette to further determine whether the spontaneous and PAR-1 receptor-evoked SICs have an astrocytic ori- 
gin. We started by studying the spread of Alexa 488 dye to establish conditions needed for complete dialysis. By patching single stratum radiatum astrocytes within $\sim 150-200$ $\mu \mathrm{m}$ of the CA1 pyramidal cell layer, we determined that $15 \mathrm{~min}$ of dialysis resulted in dialysis of $\sim 46$ astrocytes with Alexa 488 $(100 \mu \mathrm{M})$. We next repeated these experiments with $10 \mathrm{~mm}$ BAPTA as well as Alexa 488 in the pipette solution, and found that a similar number of astrocytes were coupled $(\sim 70)$ (Fig. $3 B, E)$. We also counted the number of GFP-positive astrocytes from confocal stacks from brain slices from transgenic mice expressing GFP in astrocytes. We found that these areas contained $\sim 73$ GFPpositive astrocytes. Because we could dialyze $\sim 70$ astrocytes by patching one single astrocyte with BAPTA and Alexa 488, and because $\sim 73$ GFP-positive astrocytes were found in the same area, we conclude that our dialysis protocol results in BAPTA loading into most of the available astrocytes.

Using the aforementioned protocol for astrocyte dialysis, we then recorded from pyramidal neurons within $150-200 \mu \mathrm{m}$ of the patched astrocyte to determine whether PAR-1 receptor-evoked SICs occurred. In control slices, in which the astrocytes had not been dialyzed with BAPTA, we recorded robust PAR-1 receptor-evoked SICs $(7.3 \pm 1.5$ per neuron) (Fig. $3 G)(n=9 / 15$ cells; 6 cells showed no response). However, in slices in which the astrocytes had been dialyzed with BAPTA, we recorded no spontaneous or PAR-1 receptor-evoked SICs $(0.1 \pm 0.1$ per neuron) (Fig. $3 D, G)(n=$ $8 / 8$ cells). Thus, we conclude that dialysis of the calcium chelator BAPTA selectively into astrocytes impairs PAR-1 receptorevoked SICs arriving onto pyramidal neurons, providing strong support for our hypothesis that elevation of astrocyte intracellular $\left[\mathrm{Ca}^{2+}\right]_{\mathrm{i}}$ by PAR-1 receptor agonists causes release of glutamate that activates NMDA receptors on pyramidal neurons. The data presented in supplemental Figure 2 (available at www. jneurosci.org as supplemental material) strongly suggest that $\mathrm{P}_{2} \mathrm{Y}_{1}$ and PAR-1 receptor agonists do not release astrocyte transmitter via volume-sensitive channels, simply because no such channels were detected. Our data favor the view that PAR-1 receptor activation leads to exocytosis of neurotransmittercontaining vesicles (Bowser and Khakh, 2007a).

\section{Discussion}

Using agonists of two natively expressed receptors $\left(\mathrm{P} 2 \mathrm{Y}_{1}\right.$ and PAR-1) within astrocytes, we show that (1) both agonists elevate $\left[\mathrm{Ca}^{2+}\right]_{\mathrm{i}}$ within astrocytes to an equal level, and (2) only activation of the PAR-1 receptor leads to neuronal consequences in the form of NMDA receptor-mediated SICs. This difference in the neuronal impact of activating $\mathrm{P}_{2} \mathrm{Y}_{1}$ and $\mathrm{PAR}-1$ receptors may relate to the modes of exocytosis that these agonists trigger (Bowser and Khakh, 2007a), or the spatial location of the glutamate release sites. For instance, we have shown that only PAR-1 receptor-mediated astrocyte excitation results in full fusion forms of exocytosis (Bowser and Khakh, 2007a), and that ATPevoked exocytosis largely, if not solely, affects other astrocytes (Bowser and Khakh, 2007b). In contrast, activation of astrocyte
PAR-1 receptors triggers glutamate release (Bowser and Khakh, 2007a) and activation of extrasynaptic NMDA receptors on pyramidal neurons.

Interestingly, our data show that agonists of $\mathrm{P}_{2} \mathrm{Y}_{1}$ and PAR-1 receptors equally increased astrocyte $\left[\mathrm{Ca}^{2+}\right]_{\mathrm{i}}$ levels, but that the PAR-1-mediated $\left[\mathrm{Ca}^{2+}\right]_{\mathrm{i}}$ transients were of longer duration. Might the differences in neuronal SIC generation resulting from $\mathrm{P}_{2} \mathrm{Y}_{1}$ and PAR-1 receptor activation be attributable to the fact that $\left[\mathrm{Ca}^{2+}\right]_{\mathrm{i}}$ remains elevated for a longer time after PAR-1 activation? We cannot rule this possibility out. However, new methods will be needed to probe this systematically and reliably. This is because rapidly applying and removing $\mathrm{P}_{2} \mathrm{Y}_{1}$ and PAR-1 agonists in multicellular brain slice preparations is not possible, and so a pharmacological approach to control the duration of agonistevoked $\left[\mathrm{Ca}^{2+}\right]_{\mathrm{i}}$ transient is problematic. These problems are compounded by the fact that $\mathrm{P}_{2} \mathrm{Y}_{1}$ receptor agonists are ATP analogues and are thus labile. Moreover, agonists of PAR-1 receptors are peptides with slow penetration into slices. In the future, it may be useful to precisely control astrocyte $\left[\mathrm{Ca}^{2+}\right]_{\mathrm{i}}$ levels by light-evoked activation of channelrhodopsin 2, which allows significant calcium flux into cells (Nagel et al., 2003). This channel has been used to excite neurons (Boyden et al., 2005), but because of its significant divalent cation permeability, it should prove useful for optical calcium excitation of astrocytes in transgenic mice (Nagel et al., 2003). This possibility will be systematically explored in future work.

How do our studies relate to other recent work for the stratum radiatum of the hippocampus? The fact that we could measure spontaneous SICs and increases in their frequency by exciting astrocytes is consistent with previous work with DHPG, and flash photolysis of caged calcium (Fellin et al., 2004). We note that the osmolarity of our solutions was constant, and so the recent proposition that 
SICs are attributable to hypo-osmotic stimuli (Fiacco et al., 2007) does not apply. However, our findings do not detract from the approach of activating exogenously expressed MrgAl receptors that failed to show SICs on pyramidal neurons (Fiacco et al., 2007). Indeed, Fiacco et al. (2007) argued that the method of elevating astrocyte $\left[\mathrm{Ca}^{2+}\right]_{\mathrm{i}}$ levels is key to whether glutamate release can occur. However, their approach assumes that MrgA1 receptors produce $\left[\mathrm{Ca}^{2+}\right]_{\mathrm{i}}$ signals like those for native receptors. This was the case in terms of the peak change in fluorescence for a calcium indicator dye, but our experiments show that this linear extrapolation to a downstream effect (i.e., signaling to neurons) is not straightforward. Of relevance is the novel observation reported here that two natively expressed receptors produced similar peak changes in $\left[\mathrm{Ca}^{2+}\right]_{\mathrm{i}}$ but produced distinct effects on neurons. On the other hand, both receptors are known to trigger exocytosis (Bowser and Khakh, 2007a). Our data suggest that when astrocyte $\left[\mathrm{Ca}^{2+}\right]_{\mathrm{i}}$ levels are appropriately elevated, by activating native PAR-1 receptors, glutamate release does occur with neuronal consequences (Lee and Haydon, 2007). Overall, our data underscore the need for caution when interpreting astrocyte $\left[\mathrm{Ca}^{2+}\right]_{\mathrm{i}}$ imaging data, especially with exogenous receptors whose targeting in spatially distinct aspects of astrocytes is not documented. More generally, our data show that the relationship between astrocyte $\left[\mathrm{Ca}^{2+}\right]_{\mathrm{i}}$ excitability and neuronal impact is not binary.

\section{References}

Araque A, Li N, Doyle RT, Haydon PG (2000) SNARE protein-dependent glutamate release from astrocytes. J Neurosci 20:666-673.

Araque A, Carmignoto G, Haydon PG (2001) Dynamic signalling between astrocytes and neurons. Annu Rev Physiol 63:795-813.

Bezzi P, Gundersen V, Galbete JL, Seifert G, Steinhäuser C, Pilati E, Volterra A (2004) Astrocytes contain a vesicular compartment that is competent for regulated exocytosis of glutamate. Nat Neurosci 7:613-620.

Bowser DN, Khakh BS (2004) ATP excites interneurons and astrocytes to increase synaptic inhibition in neuronal networks. J Neurosci 24:8606-8620.

Bowser DN, Khakh BS (2007a) Two forms of single vesicle astrocyte exocytosis imaged with total internal reflection fluorescence microscopy. Proc Natl Acad Sci USA 104:4212-4217.

Bowser DN, Khakh BS (2007b) Vesicular ATP is the predominant cause of intercellular calcium waves in astrocytes. J Gen Physiol 129:485-491.

Boyden ES, Zhang F, Bamberg E, Nagel G, Deisseroth K (2005) Millisecondtimescale, genetically targeted optical control of neural activity. Nat Neurosci 8:1263-1268.

Bushong EA, Martone ME, Jones YZ, Ellisman MH (2002) Protoplasmic astrocytes in CA1 stratum radiatum occupy separate anatomical domains. J Neurosci 22:183-192.

Cornell-Bell AH, Finkbeiner SM, Cooper MS, Smith SJ (1990) Glutamate induces calcium waves in cultured astrocytes: long-range glial signaling. Science 247:470-473.

Evanko DS, Zhang Q, Zorec R, Haydon PG (2004) Defining pathways of loss and secretion of chemical messengers from astrocytes. Glia 47:233-240

Fellin T, Pascual O, Gobbo S, Pozzan T, Haydon PG, Carmignoto G (2004) Neuronal synchrony mediated by astrocytic glutamate through activation of extrasynaptic NMDA receptors. Neuron 43:729-743.

Fiacco TA, Agulhon C, Taves SR, Petravicz J, Casper KB, Dong X, Chen J, McCarthy KD (2007) Selective stimulation of astrocyte calcium in situ does not affect neuronal excitatory synaptic activity. Neuron 54:611-626.

Fields RD (2004) The other half of the brain. Sci Am 290:54-61.

Fields RD, Burnstock G (2006) Purinergic signalling in neuron-glia interactions. Nat Rev Neurosci 7:423-436.

Fonnum F, Johnsen A, Hassel B (1997) Use of fluorocitrate and fluoroacetate in the study of brain metabolism. Glia 21:106-113.

Garcia AD, Doan NB, Imura T, Bush TG, Sofroniew MV (2004) GFAPexpressing progenitors are the principal source of constitutive neurogenesis in adult mouse forebrain. Nat Neurosci 7:1233-1241.
Gordon GR, Baimoukhametova DV, Hewitt SA, Rajapaksha WR, Fisher TE, Bains JS (2005) Norepinephrine triggers release of glial ATP to increase postsynaptic efficacy. Nat Neurosci 8:1078-1086.

Haydon PG (2001) GLIA: listening and talking to the synapse. Nat Rev Neurosci 2:185-193.

Hirase H, Qian L, Barthó P, Buzsáki G (2004) Calcium dynamics of cortical astrocytic networks in vivo. PLoS Biol 2:E96; 494-499.

Jaiswal JK, Fix M, Takano T, Nedergaard M, Simon SM (2007) Resolving vesicle fusion from lysis to monitor calcium-triggered lysosomal exocytosis in astrocytes. Proc Natl Acad Sci USA 104:14151-14156.

Jourdain P, Bergersen LH, Bhaukaurally K, Bezzi P, Santello M, Domercq M, Matute C, Tonello F, Gundersen V, Volterra A (2007) Glutamate exocytosis from astrocytes controls synaptic strength. Nat Neurosci 10:331-339.

Junge CE, Lee CJ, Hubbard KB, Zhang Z, Olson JJ, Hepler JR, Brat DJ, Traynelis SF (2004) Protease-activated receptor-1 in human brain: localization and functional expression in astrocytes. Exp Neurol 188:94-103.

Khakh BS, Gittermann D, Cockayne DA, Jones A (2003) ATP modulation of excitatory synapses onto interneurons. J Neurosci 23:7426-7437.

Kofuji P, Newman EA (2004) Potassium buffering in the central nervous system. Neuroscience 129:1045-1056.

Kreft M, Stenovec M, Rupnik M, Grilc S, Krzan M, Potokar M, Pangrsic T, Haydon PG, Zorec R (2004) Properties of Ca(2+)-dependent exocytosis in cultured astrocytes. Glia 46:437-445.

Krzan M, Stenovec M, Kreft M, Pangrsic T, Grilc S, Haydon PG, Zorec R (2003) Calcium-dependent exocytosis of atrial natriuretic peptide from astrocytes. J Neurosci 23:1580-1583.

Lee CJ, Mannaioni G, Yuan H, Woo DH, Gingrich MB, Traynelis SF (2007) Astrocytic control of synaptic NMDA receptors. J Physiol (Lond) 581:1057-1081.

Lee SY, Haydon PG (2007) Astrocytic glutamate targets NMDA receptors. J Physiol (Lond) 581:887-888.

Liu QS, Xu Q, Arcuino G, Kang J, Nedergaard M (2004) Astrocyte-mediated activation of neuronal kainate receptors. Proc Natl Acad Sci USA 101:3172-3177.

Nagel G, Szellas T, Huhn W, Kateriya S, Adeishvili N, Berthold P, Ollig D, Hegemann P, Bamberg E (2003) Channelrhodopsin-2, a directly lightgated cation-selective membrane channel. Proc Natl Acad Sci USA 100:13940-13945.

Newman EA (2003a) Glial cell inhibition of neurons by release of ATP J Neurosci 23:1659-1666.

Newman EA (2003b) New roles for astrocytes: regulation of synaptic transmission. Trends Neurosci 26:536-542.

Parpura V, Haydon PG (2000) Physiological astrocytic calcium levels stimulate glutamate release to modulate adjacent neurons. Proc Natl Acad Sci USA 97:8629-8634.

Parri HR, Crunelli V (2003) The role of Ca2 + in the generation of spontaneous astrocytic Ca2 + oscillations. Neuroscience 120:979-992.

Parri HR, Gould TM, Crunelli V (2001) Spontaneous astrocytic Ca2 + oscillations in situ drive NMDAR-mediated neuronal excitation. Nat Neurosci 4:803-812.

Perea G, Araque A (2005) Properties of synaptically evoked astrocyte calcium signal reveal synaptic information processing by astrocytes. J Neurosci 25:2192-2203.

Porter JT, McCarthy KD (1996) Hippocampal astrocytes in situ respond to glutamate released from synaptic terminals. J Neurosci 16:5073-5081.

Tritsch NX, Bergles DE (2007) Defining the role of astrocytes in neuromodulation. Neuron 54:497-500.

Weinstein JR, Gold SJ, Cunningham DD, Gall CM (1995) Cellular localization of thrombin receptor mRNA in rat brain: expression by mesencephalic dopaminergic neurons and codistribution with prothrombin mRNA. J Neurosci 15:2906-2919.

Zhang Q, Pangrsic T, Kreft M, Krzan M, Li N, Sul JY, Halassa M, Van Bockstaele E, Zorec R, Haydon PG (2004a) Fusion-related release of glutamate from astrocytes. J Biol Chem 279:12724-12733.

Zhang Q, Fukuda M, Van Bockstaele E, Pascual O, Haydon PG (2004b) Synaptotagmin IV regulates glial glutamate release. Proc Natl Acad Sci USA 101:9441-9446. 